\title{
Public Hearings
}

\section{By Mariem Guellouz and Selima Kebaili}

The court sessions that attract public attention this year in Tunisia are of a very different type than those held in Egypt [ $\nearrow$ Court Trials]. In November, the first public hearings of the victims of Ben Ali's dictatorship in Tunisia take place. They are expected to unveil the political repression committed under the authoritarian regimes [ $\lambda$ "The System" $v S_{\text {s. }}$ "The People", オPrison]. This moment of truth-revealing is one of the pillars of the process of transitional justice, constitutionally endorsed by Tunisia in 2013. Transitional justice means a set of judicial mechanisms and conflict resolution procedures set up in the aftermath of conflict or dictatorship. Truth revealing, reparations to victims, guarantees of non-recurrence and, ultimately, reconciliation, are expected to lead to the pacification and democratization of societies. In this context, in Tunisia, the victims are asked to submit a file attesting to the violations committed against them to the Truth and Dignity Commission (Instance Vérité et Dignité, IVD / Hay'at al-Haqīqa wa'l-Karāma). Created in 2013 for a five-year term, this committee is the central body of the transitional justice process. Its members, including its particularly controversial [ $\nearrow$ Clash] President Sihem Bensedrine (Sihām Bin Sidrīn), are appointed by the Constituent Assembly, which is composed of a majority of the Nahḍa Party. The prerogatives of the institution are broad -its members are in charge of assessing the bases of compensation for victims and defining the criteria of this compensation. Accordingly, expectations and hopes are high [ 7 Hope $v s$. Hell].

In particular, the IVD is responsible for holding hearings with victims, "collecting information as well as locating, identifying, recording, confirming and archiving violations in order to build a database and develop a unified register of victims of violations" (MDHJTT). The period of abuses that shall be dealt with in the hearings is long, ranging from July 1, 1955, to December 25, 2013, covering the regimes of Bourguiba (1956-1987), Ben Ali (1987-2011) [ 7 Father Figures], and the first post-revolutionary governments (20112013). It is therefore a question of retracing and documenting, through the testimonies of 55,000 victims, more than fifty years of state-sanctioned violence and all kinds of other repression.

On November 17, at 8:30 pm, Tunisian men and women are able to follow the first public hearings on their television screens. They are taking place at Club Alyssa, a place of social receptions formerly reserved for the executives of the Ben Ali regime. In a packed auditorium, political leaders, journalists, researchers, members of Tunisian and international NGOs and members of the victims' families have come to listen to the testimonies. Women sitting in the front row are bearing on their knees portraits of their sons. One of the mothers, Ourida Kadousi, is the first to speak. She tells how her son, Raouf Kadoussi, 27 years old, was shot and killed on January 8, 2011, by the police while demonstrating [ $\nearrow$ The Policeman Criminal]. She claims her right to live the "head up" (OMRI).

Mehrezia El-Abed, another victim, says:

Journal of Arabic and Islamic Studies 21 (2021) - Themed Section In2016: *230-*232 (C) Mariem Guellouz, Univ. Paris Descartes, FR, and Sélima Kebaïli, Univ. de Lausanne, CH 
They made me go into a room and beatings began, kicking, slapping, clothes torn off so I put my hand on my belly and one of them asked what was going on? I replied that I was three months pregnant and at that time a torturer known to excel in the torture of women started punching me on the stomach until I bleed and lose the baby.

Later in the evening, it is the turn of writer and political opponent Gilbert Naccache to speak. He begins his testimony with a tribute to the martyrs of the revolution before retracing several significant and violent events of his career as a political opponent (BASTAYEKFI).

This and the following public hearings depict the strong repression committed by the regimes of Bourguiba and Ben Ali. Several political groups had been targeted, including those of the Marxist Perspectives movement and al- 'Āmil al-Tūnisī (The Tunisian Worker), the Movement of the Islamic tendency (MTI) (precursor of Ennahdha), or the relatives of the opponent leader Salah ben Youssef (Șalāḥ Bin Yūsuf).

From the evening of the first hearing, the testimonies cause ambivalent reactions among the audience [ $\nearrow$ Clash]. The victims' reports leave their imprint on the Tunisian viewers, who react immediately, also in social networks [ $\nearrow$ Social Media]. Despite the inevitable emotion of this exercise of narrating the acts of physical and moral violations, the victims have largely kept calm and shown great modesty in their intimate reports about tragic facts. Several reactions of compassion and empathy with the victims are immediately posted on the Dignity and Truth Commission's Facebook page while the public hearings are still being transmitted. Many Internet users express their indignation about torture and the violations of human rights. On his Facebook page, Omar Fassatoui, a prominent actor in Tunisian civil society, writes:

Whether we like it or not, whether we criticize it or not, whether we say that it could have been better, whether we are more interested in the dress and the haircut of Mrs. Ben Sedrine than the testimonies of the victims and of their families, one fact remains. Yesterday we had a historic moment. We have started a huge work on the Tunisian collective memory and I hope for national reconciliation. [ $\lambda$ Past vs. Present]

However, reception is not unanimously positive. There are also negative reactions to the hearings. Some reveal a total denial of the relevance of the transitional justice procedures:

Transitional justice was created when there was no listening support; at the moment there is Facebook which carries far our voices (reference).

Other critics question the truthfulness of the victims' statements, described as lies or theatrical enactments aimed at separating the country and threatening social peace:

But who said that these testimonies are true and that the majority of the witnesses are not exaggerating (reference).

Sihem Ben Sedrine, the president of the Commission, is also criticized. She is accused of having politicized the process by giving priority to the testimonies of the victims of antiIslamist repression (BEN SAFA, GALTIER).

The polemics are characteristic of this year's public discourse about political and social issues, particularly also those related to the economic reconciliation act, an initiative of the

jais • 21 (2021) - Themed Section In2016: *230-*232 
Nidaa Tounes (Nidā’ Tūnis) party that aims to grant amnesty to several people who have committed economic and financial crimes and offenses [ 7 Manīsh msämih̆].

\section{Related entries}

ARRAYs - Clash $\downarrow$ Court Trials $\downarrow$ Father Figures $\downarrow$ In Islam, ... Manīsh msāmih $\downarrow$ The Policeman Criminal Prison $\downarrow$ Social Media

Codes - Hope vs. Hell ^ Past vs. Present " "The System" vs. "The People"

\section{References}

[BASTAYEKFI =] N. N. " "La vérité, quoi qu'on fasse, est révolutionnaire": témoignage de Gilbert Naccache devant l'Instance Vérité et Dignité tunisienne.» Bastayekfi, December 3, 2016, $<$ https://bastayekfi.wordpress.com/2016/12/03/la-verite-quoi-quon-fasse-est-revolutionnaire"temoignage-de-gilbert-naccache-devant-linstance-verite-et-dignite-tunisienne/>

BEN SAID, Safa. "Tunisia faces up to dark history with first public hearings." TRT World, November 21, 2016, <https://www.trtworld.com/in-depth/tunisia-faces-legacy-of-dictatorship-in-first-publichearing-of-victim-234641>.

GaLTIER, Mathieu. «Tunisie: Sihem Bensedrine, militante contestée : La présidente se voit reprocher une gestion à poigne. » Libération, November 16, 2016, <https://www.liberation.fr/planete/2016/ 11/16/sihem-bensedrine-militante-contestee_1528881/>.

MDHJTT: Ministère des Droits de l'Homme et de la Justice transitionnelle tunisienne. Loi organique relative à l'instauration de la justice transitionnelle et à son organisation. Décembre 2013.

OMrI, Mohamed-Salah. "Tunisia's moment of truth: process, outcomes, expectations." openDemocracy, November 24, 2016, <https://www.opendemocracy.net/en/north-africa-west-asia/tunisia-smoment-of-truth-process-outcomes-expectations/>.

\mguellouz@yahoo.fr

4 selima.kebaili@gmail.com 